\title{
V. POLEMIKA
}

\author{
DARIUSZ MAKIŁŁA (Warszawa)
}

\section{O pierwszej polskiej ustawie zasadniczej. W odpowiedzi recenzentom Tomaszowi Kucharskiemu i Zbigniewowi Naworskiemu*}

$\mathrm{Z}$ dużym zainteresowaniem zapoznałem się $\mathrm{z}$ artykułem recenzyjnym Tomasza Kucharskiego i Zbigniewa Naworskiego z napisanej przeze mnie książki poświęconej Artykułom henrykowskim. Jak sami badacze toruńscy przyznają, praca wzbudziła ich zainteresowanie - zarówno ze względu na temat, jak i na niewyczerpanie w dotychczasowych pracach wszystkich spraw wiążących się z poruszoną w omawianej monografii problematyką. Omówienie nabrało jednak polemicznego, bezkrytycznego charakteru. Stąd poczucie obowiązku nie pozwala mi przejść obok ich tekstu obojętnie i wymaga uporządkowania materii poruszonych $w$ recenzji, tak aby wynikający z tego obraz był bardziej zrozumiały dla odbiorców, a przesłanie płynące ze sporządzonego przez recenzentów omówienia jasne.

I. Recenzję cechują uproszczenia i przeinaczenia dotyczące treści monografii, sprzyjające wprowadzaniu czytelnika w błąd. Tak jest chociażby ze stwierdzeniami, że tytuł nie odpowiada treści publikacji - co samo w sobie jest nieprawdziwe, oraz że przedmiotem rozważań pierwszej części pracy są „tylko kwestie bezpośrednio związane z rozwojem sytuacji w bezkrólewiu po śmierci Zygmunta Augusta".

Recenzenci zdają się nie dostrzegać, że ta część pracy poświęcona została nie dziejom bezkrólewia, ale powstaniu Artykułów henrykowskich, ich formie prawnej, podlegającej w latach 1573-1576 ewolucji oraz procesowi nadawania im mocy obowiązującej. Co więcej, nie widzą, że między omówieniem

* Tomasz Kucharski i Zbigniew Naworski, Kilka uwag o najnowszej ocenie artykułów henrykowskich. W zwiazku z praca Dariusza Makilly, ,Artykuly henrykowskie. Geneza-Obowiazywanie - Stosowanie. Studium historyczno-prawne”. Wyd. Vizja Press \& IT, Warszawa 2012, „Czasopismo Prawno-Historyczne", t. 65, 2013, z. 2. 
w pierwszej części monografii - genezy Artykułów - jako aktu konstytucyjnego, mającego fundamentalne znaczenie dla ustroju Rzeczypospolitej, kiedy należy wyjaśnić okoliczności związane z procesem przyjmowania i nabierania mocy obowiązującej Artykułów henrykowskich a genezą artykułów, jako poszczególnych norm, dokonaną w drugiej części monografii, kiedy omawiany jest przedmiot Artykułów - nie ma sprzeczności.

Za nietrafne uważam wywody recenzentów dotyczące obowiązywania i stosowania Artykułów henrykowskich, co stanowi zasadniczy problem w trzeciej części monografii. Rozważania autorów recenzji - niewolne od dygresji i pouczeń - są o tyle nietrafne, że między nadaniem mocy obowiązującej, następującym w przypadku Artykułów henrykowskich w drodze określonego procesu, trwającego od 1573 do 1576 r., a obowiązywaniem, występującym w znaczeniu utrzymywania się ich ważności - zachodzi zasadnicza różnica. Niekoniecznie też - jak chcieliby recenzenci - problem obowiązywania musiał być artykułowany w postaci osobnej monografii. Można go również ująć na tle dziejów - jak to zresztą zostało poczynione. Zaprzeczyć przy tym należy, jakoby omówienie tego problemu musiało obejmować wszelkie podane przez nich propozycje. Stwierdzenie bowiem recenzentów, że dla kwestii obowiązywania „odpowiedniejsze byłoby ustalenie wpływu na „obowiązywanie" [Artykułów] uchwalania nowych konstytucji sejmowych w materii prawa ustrojowego, czyli konstytucji” - jak należy się domyślać - „mających istotny wpływ na zakres przedmiotowy Artykułów, które dokonywałyby w nich zmian, podyktowanych potrzebami chwili bądź zmieniałyby zasięg ich oddziaływania" - nie znajduje uzasadnienia. Problem bowiem w tym, że konstytucji, które odwoływałyby się do Artykułów bezpośrednio, a nie pośrednio je modyfikując, względnie ograniczając ich zasięg - nie było.

Podobnie jest $\mathrm{z}$ inną dygresją, jakiej dokonali recenzenci w stosunku do „stosowania Artykułów”. Obejmuje ono bowiem nie tylko sformalizowane działania kompetentnych organów władzy publicznej (lub upoważnionych przez nią innych organów i osób), polegające na podejmowaniu i realizowaniu decyzji władczych, indywidualnych i konkretnych, ale zawiera także czynności, które pojmować można w rozumieniu ,potocznym”, odnoszącym się do faktu czy stanu istnienia czegoś, co przez swoje funkcjonowanie nabiera również prawnego znaczenia. Czy pojęcie stosowania Artykułów henrykowskich łączyć można więc wyłącznie ze ściśle przewidzianym w nauce prawoznawstwa pojęciem stosowania prawa? Otóż nie. Chodzi bowiem o zupełnie inne rozumienie tego pojęcia, aniżeli polegające jedynie na posługiwaniu się normą prawną w celu jej władczego zastosowania. Bardziej odnosi się to bowiem do pojmowania pojęcia ,stosowanie”, odpowiedniego zwłaszcza w odniesieniu do stosunków politycznych. Takie rozumienie stosowania jest z pewnością uprawnione także wówczas, kiedy mamy do czynienia z funkcjonowaniem aktu prawnego, zwłaszcza o charakterze zasadniczym. Czy w ta- 
kim przypadku praktyka, polegająca na odwoływaniu się do aktu prawnego, przywoływaniu go w określonych sytuacjach, odnoszenie się do niego bądź powoływanie się na akt prawny - ale również - nieczynienie tego wszystkiego, co zostało wymienione - mimo nawet świadomości, że akt prawny obowiązuje - nie jest również stosowaniem prawa? Wprawdzie takie pojęcie „stosowania” niekoniecznie daje się odnieść do sui generis techniki prawniczej, ale pozwala na posłużenie się pojęciem stosowania aktu prawnego, chociażby w rozumieniu politycznym. Brak jakiejkolwiek reakcji na istnienie obowiązującego aktu prawnego, nie odwoływanie się do niego - jak to coraz częściej w stosunku do Artykułów henrykowskich, począwszy od pierwszej połowy XVII w., a nagminnie wręcz w XVIII w. bywało - jest przecież także stosowaniem aktu prawnego.

II. Z wieloma uwagami dotyczącymi konstrukcji pracy, rozrzuconymi po różnych częściach ich wystąpienia, trudno mi się zgodzić. Recenzentom nie podoba się kształt poszczególnych części oraz rozdziałów. Autorzy recenzji zdają się nie dostrzegać, że przedmiotem pracy są dzieje aktu konstytucyjnego, co determinuje sposób prezentacji według pewnej kolejności wydarzeń: od okoliczności związanych z jego powstaniem, ewolucji jego formy prawnej i nadaniem mu mocy obowiązującej, przez omówienie przedmiotu aktu, po jego dzieje w praktyce politycznej Rzeczypospolitej.

Trudno zatem zgodzić się ze stwierdzeniem, że w rozdziale pierwszym powinno się przedstawić „losy poprawy prawa - jak zaznaczają - w latach 1572-1576" - co samo w sobie jest błędne. Autorzy recenzji powinni natomiast pamiętać, że o ,poprawie prawa” mówiono w Rzeczypospolitej w okresie bezkrólewia, ale nie w latach, jak to podnoszą recenzenci, 1572-1576, a co najwyżej do maja 1573 r. Z chwilą bowiem, kiedy Artykuły, pochodzące z 12 maja 1573 r., a będące z pewnością efektem dążeń do „poprawy prawa” przyjęto, proces ten definitywnie się zakończył. Jeśli problem ten się w późniejszym czasie pojawiał, to już w innym kontekście.

Nie zgodziłbym się także $\mathrm{z}$ sugestią recenzentów, że stanowiące treść drugiego i trzeciego rozdziału części pierwszej monografii omówienie form prawnych występowania Artykułów, można było połączyć z kwestią nadawania mocy obowiązującej. Trzeba podkreślić, że w przypadku Artykułów henrykowskich połączenie obu kwestii nie oznacza bynajmniej ich tożsamości, czy nawet jednoznaczności. Kwestionuję wreszcie stwierdzenie, że sprawy te są nierozerwalnie z sobą związane. Recenzenci nie uwzględniają, że forma prawna występowania Artykułów - od zbioru praw, dołączonego do osobnej uchwały Stanów, w której zbiór ten przyjmowano, a których intencją byłoby jego potwierdzenie przez elekta, dokonane przez formalne nadanie zbiorowi praw postaci przywileju monarszego, który ogłoszony został w konstytucji sejmu koronacyjnego w 1576, stając się ustawą - była rezultatem pewnej 
ewolucji, mającej swoje korzenie w zamiarach pomysłodawców zbioru praw. W sprawie tej należy ponadto wyraźnie odróżniać zamiary stanów od rezultatu ich działania, zależnego od ich postawy, a także od elekta i zmiennych okoliczności zewnętrznych. Nie wolno również zapominać, że w przypadku Artykułów henrykowskich mieliśmy do czynienia z dziejami aktu prawnego, którego forma prawna podlegała wyjątkowo częstym zmianom, i to jeszcze wtedy, zanim formalnie wszczęto czynności zmierzające do nadania aktowi stanów mocy obowiązującej. Czy można więc kwestie te rozdzielać? Można, tym bardziej, iż każdy z tych problemów miał inny kontekst, jak i również perspektywę spojrzenia, a przede wszystkim stanowił odrębny problem, mający swoją własną dynamikę działań. Wzajemne odniesienia były nie do uniknięcia, ale jeśli już zostały poczynione, to jednak przede wszystkim następowały one w kontekście innego spojrzenia na każdą ze spraw.

Nieuzasadniona wydaje mi się zwłaszcza uwaga recenzentów, że w pracy zakłócone zostały proporcje między prezentacją drugiej części pracy, poświęconej przedmiotowi Artykułów, a trzecią częścią, dotyczącą kwestii ich obowiązywania oraz stosowania w praktyce politycznej. Kwestionują oni w odniesieniu do części drugiej „przedmiotowo instytucjonalny” podział norm. Odnosząc się do tego zarzutu, należy zauważyć, że przeprowadzenie sui generis komentarza, co w przypadku aktów prawnych jest zasadą powszechnie stosowaną, może się odbyć na dwa sposoby. Pierwszą, uproszczoną metodą, niejako ad usum delphini, omówienie zawartości aktu prawnego można przedstawić w sposób nieskomplikowany, najlepiej po kolei. Można jednak dokonać omówienia treści aktu prawnego drugą metodą, problemową. Nakłada ona na badacza obowiązek nie tylko podjęcia próby zastanowienia się nad wieloma szczegółami, związanymi z historią przygotowania aktu, rozważenia kontekstu jego powstawania, a także ustalenie okoliczności, mających wpływ na jego ukształtowanie, czy też spróbowanie dotarcia do intencji jego pomysłodawców. Takie zadanie wymaga uporządkowania całego aktu, wydobycia zawartego w nich porządku, głębszej myśli, która - ze względu na wagę okoliczności, w jakich powstawał oraz cele, jakie starano się mu nadać, ale również intencje, przyświecające jego twórcom - były i rządziły konstrukcją aktu. Jeśli przedmiotem omówienia jest akt konstytucyjny o charakterze zasadniczym, stanowiący opis ustroju państwa, w którym zawsze będzie występowała część dotycząca organizacji państwa, a więc poświęcona organom i instytucjom, jak też ich wzajemnym relacjom, a obok nich będzie zamieszczona część dotycząca praw i wolności wraz z gwarancjami ustrojowymi - wówczas jedynym możliwym podziałem norm, jakiego można dokonać w przypadku ich omówienia, jest podział instytucjonalno-przedmiotowy. Innej możliwości, przy problemowym omówieniu zawartości danego aktu, po prostu nie ma.

Stąd recenzenci błędnie uznają, że zawarty w drugim rozdziale części trzeciej podział na regulacje dotyczące relacji króla z sejmem, senatorów re- 
zydentów, prawa obsadzania urzędów, sądownictwa, przeprowadzania elekcji i spraw wyznaniowych, jest podziałem przedmiotowym. Zdają się nie zauważać, że w swoich wywodach dotykają dwóch różnych sfer działania. Chciałbym podkreślić, że komentarz do aktu, zwłaszcza historycznego, w którym dokonuje się częstokroć egzegezy i analizy historyczno-dogmatycznej, w odniesieniu do norm kształtujących się trakcie dziejów - w której możliwość stosowania powątpiewają - przydatnej w ukazaniu ewolucji pojęć, ustaleniu ich brzmienia i analizy dogmatycznej w ujęciu historycznym, jak również genezy i rozwoju poszczególnych instytucji ustrojowych, od ich początków po nadanie określonego ustawowego kształtu - jest czymś innym od komentarza do wydarzeń, związanych z jego stosowaniem w aktualnej praktyce prawnej i politycznej, w której znana im tylko ahistorycza metoda formalno-dogmatyczna znajduje zastosowanie. Stąd podział norm i ich omówienie, dokonane w tej części monografii miało charakter nie tyle podziału przedmiotowego, ile bardziej podziału funkcjonalnego, odnoszącego się do funkcjonowania norm Artykułów w praktyce politycznej. Stwierdzenie recenzentów, że konstrukcję pracy burzy fakt, iż analiza wydarzeń po wejściu Artykułów w życie w 1576 r., nie dotyczyła całości przedmiotu Artykułów, jest po prostu mylne. Gdyby recenzenci głębiej przyjrzeli się materii problemowej, dostrzegliby, że Artykuły obowiązywały i mocy ich nikt nie kwestionował - co najwyżej nie odwoływano się do nich nagminnie. Problemy pojawiały się dopiero na tle praktyki politycznej w razie naruszania poszczególnych punktów Artykułów henrykowskich, a nie całego zakresu przedmiotowego Artykułów, czy tym bardziej całości ustawodawstwa, które było już wówczas dość rozległe, i które przedmiotowo w różnym czasie nawiązywało do wielu postanowień Artykułów. I tylko w kontekście naruszeń norm Artykułów oraz w ich zakresie można było sprawę przestrzegania, czy też stosowania Artykułów w praktyce politycznej potraktować. W taki również sposób zostało to ujęte w mojej monografii.

Za nietrafną należy uznać argumentację recenzentów, że w odniesieniu do części trzeciej następowało w monografii przeplatanie się dwóch rzeczywistości: ,prawnej (ocena mocy obowiązującej Artykułów w obliczu przemian prawnych) oraz praktycznej (ocena sporów politycznych wokół Artykułów oraz prawidłowości ich stosowania w obliczu przemian politycznych)”. Nie spostrzegli oni, że nie o to w rozdziale drugim trzeciej części chodziło - i nie na takim postrzeganiu kwestii obowiązywania oraz stosowania Artykułów w drugiej połowie XVI w. - problem ten był osadzony. Czynnik polityczny odgrywał w ówczesnej rzeczywistości najistotniejszą rolę, co powodowało, że nie dominowały wówczas spory prawne, związane z przestrzeganiem Artykułów - tych bowiem w ówczesnej rzeczywistości po prostu nie było. O sposobie natomiast stosowania Artykułów decydowała mniej lub bardziej bieżąca polityka, a ta kierowała się innymi regułami. Nie tyle, że co rusz pojawiały się 
w niej Artykuły - bo do nich jakby się bezpośrednio nie odwoływano - ale zdarzały się sprawy, nierzadko rodzące konflikty, których meritum znajdowało odniesienie wprost czy pośrednio do Artykułów. I wyłącznie w kontekście praktyki politycznej - niewolnej przecież od politycznej walki - należy postrzegać sprawy będące jej przedmiotem. Stąd stawianie tezy, że wszystkie kwestie dotyczące Artykułów autor „starał się opisać razem” - nie odpowiada rzeczywistości.

Za podobnie nieupoważnione należy uznać przekonanie recenzentów, że w części trzeciej pominięte czy też nierozbudowane zostały pewne ważne wątki. Celem bowiem pracy nie było tworzenie samoistnych i odrębnych studiów z zakresu ogólnej historii politycznej Rzeczypospolitej, czy też odrębnych monografii poświęconych bardziej jej szczegółowym zagadnieniom. Kwestie te zostały ujęte po prostu w takich proporcjach, jakie niezbędne były do przedstawienia problemu dotyczącego Artykułów henrykowskich. Postulat tworzenia de facto pracy amorficznej - jak chcieliby zdaje się recenzenci budowanej na przeroście wątków, wikłającej się w rozważania odciągające od istoty sprawy, jest całkowicie bezzasadny. Wprawdzie autorzy recenzji zauważają, że próba umieszczenia wszystkiego w monografii byłoby zadaniem karkołomnym, nie uznają jednakże, aby miało to zwalniać autora z obowiązku pisania o wszystkim - co samo w sobie jest już niekonsekwencją.

III. Przechodzę do spraw merytorycznych. Problemy, jakimi zajęli się recenzenci, skoncentrowały się wokół kilku kwestii, z zasady niepowiązanych ze sobą. Skupiły się one na rozważaniach dotyczących klasyfikacji norm, terminologii oraz kilku wybranych - chyba przypadkowo, bo nie układających się w jakąś całość - zagadnień, do których zaliczyć można sprawy elekcji, sejmu, regale górniczego, praw fundamentalnych i kardynalnych.

Poza krytyką kwalifikacji pewnych wybranych norm Artykułów, autorzy recenzji nie wskazali na alternatywną propozycję przeprowadzenia ich podziału. Ich komentarze dotyczące poszczególnych punktów Artykułów są jak sądzę - dowodem schematyzmu i powierzchowności myślenia. Pokutuje u nich podręcznikowy sposób przekazywania treści Artykułów henrykowskich - powrót do tezy, że były to normy ,skonstruowane według jednolitego schematu tzn. nakładające prawne obowiązki na króla, jako organ władzy, które wyliczało się dotąd najczęściej bez zatrzymania, jednym tchem. Tymczasem Artykuły henrykowskie były aktem konstytucyjnym, dokonującym opisu ustroju - oczywiście, że w sposób niepełny i niedoskonały, ale jednak już formalny - w którym król był składnikiem istotnym, ale nie wyłącznym, chociaż z jego powodu akt ten powstał. Właśnie dlatego, że starano się w ustroju „znaleźć mu miejsce”, wprowadzano zmiany w ustroju, które dotyczyły osadzenia w nim wszystkich trzech czynników instytucjonalnych, króla, sejmu oraz rady królewskiej, a ponadto pokazywano te z prawnych atrybutów su- 
werena, jakim był naród szlachecki, w postaci właśnie jego praw i wolności, wspartych określonymi gwarancjami ustrojowymi. I w tym miejscu wyjaśnia się, dlaczego pewne pojęcia, które uznano z określonego punktu widzenia za prawa, czy też wolności, a które stały się nimi przede wszystkim dopiero później - przyporządkowane zostały, zgodnie z intencjami ich twórców w okresie powstawania Artykułów henrykowskich - instytucjom ustrojowym. Exemplum takiego podejścia stanowią chociażby podane przez recenzentów przykłady wolnej elekcji królów, korzystania z wojska, ,gremiów doradczokontrolnych" (kiedy różnice między organami doradczymi oparte były raz na normach kompetencyjnych, gdy chodziło o radę królewską, innym razem na organizacyjnych, kiedy dotyczyły odrębnego organu, jakim byli senatorowie rezydenci), czy też przykładów odnoszących się do „powiązań między normą dotyczącą korony i skarbca oraz stosowania ,pieczęci pokojowej”, czy prywatnej do spraw publicznych". Odmiennie - wbrew recenzentom - należy podejść do „głosu wolnego" na sejmie, będącego przecież zasadą postępowania, znaną wówczas, pozwalającej każdemu zabrać głos wobec króla, ale sformułowanej jako prawo wiele lat po wprowadzeniu Artykułów), czy też spraw podatkowych, o których się przecież w Artykułach bezpośrednio nie traktuje.

Jeszcze bardziej znamienne są wywody recenzentów dotyczące problemu terminologii związanej z procesem nabierania mocy prawnej przez Artykuły, podczas którego pewne okoliczności czy też zdarzenia miały znaczenie polityczne, ale zarazem prawne. Nie chodziło więc w całej sprawie o „przyznanie elektowi prawa do nadawania sankcji” oraz że „wejście w życie Artykułów” następowało - jak to autorzy recenzji określili - „na podstawie wydanego przez koronowanego monarchę przywileju" - chociaż taką formę nadano pierwotnie propozycji zbioru praw przedłożonemu elektowi przez przedstawicieli Stanów. Nie miało to również miejsca - jak podnoszą recenzenci - w ,uchwalonej na sejmie koronacyjnym nowej konstytucji”, zaś zastosowanie pojęcia „sankcja” oznaczałaby nadanie mocy pierwotnej uchwale stanów, podniesionej do rangi konstytucji sejmowej poprzez jej zatwierdzenie ex post". Rzecz polegała bowiem na tym, że we wspomnianym procesie nadawania mocy obowiązującej, który rozciągnął się na lata 1573-1576, miały miejsce różne zdarzenia. Należały do nich zarówno przyjęcie i potwierdzenie aktów, będących na tym etapie jedynie projektem prawa (nie jak to przytoczyli recenzenci, ,projektem legislacyjnym”, albowiem takiego pojęcia w monografii, a tym bardziej na podanej przez nich stronie, nie ma), przedkładanego przez Stany, a potwierdzanego przez rex electus, dalej przysięga złożona podczas koronacji, sama koronacja, jak również potwierdzenie praw nowych, a tutaj Artykułów, dokonanych jako czynność niezbędna dla nadania mocy obowiązującej przez rex iam coronatus, co wynikało z zobowiązań do ich potwierdzenia, przyjętych w umowie z elektem, jaką były pakta konwenta. Czynności te stały się udziałem dopiero króla Stefana, mającego ciągle odrębną od Stanów 
podmiotowość, który mógł nadać sankcję aktom stanowym - co w zasadzie oznaczało ich zatwierdzenie. Ogłoszenie tego następnie w konstytucji sejmowej nadawało tym aktom charakter normy, która ze względu na swoją rangę nabierała znaczenia zasadniczego. Wszystkie te działania były czynnościami, które miały w tym procesie swoje miejsce.

W tym kontekście przywołany przez recenzentów przykład osiągania konsensusu (zamiast nadawania sankcji na przykładzie praktyki parlamentarnej) jest o tyle nietrafny, że dotyczył on obrad sejmu z czasów, kiedy król stawał się i był uczestnikiem obrad. Nie uwzględniał on natomiast swoistości działania sejmu w okresie bezkrólewia, kiedy Rzeczpospolitą stanowiły stany, które podejmując uchwały, dokonywały tego jedynie w swoim imieniu, zaś dla uzyskania prawomocności niezbędna była zgoda trzeciego czynnika ustawodawczego, czyli króla. Sytuacja powodowała, że w bezkrólewiu w sposób nieunikniony pojawiały się dwie strony całego postępowania, a mianowicie Stany, a z drugiej strony król elekt, z którym, za pośrednictwem jego przedstawicieli, należało ułożyć się w celu przyjęcia i potwierdzenia uchwalonych podczas obrad sejmu w bezkrólewiu praw. Sprawa ta nabierała ostrości szczególnie podczas bezkrólewi w 1. 1573-1576, kiedy tworzono pewną praktykę, zaś podejście do nowej sytuacji nie było w pełni ustabilizowane. Ze względu ponadto na wagę oraz charakter podjętych decyzji w zakresie praw świeżo uchwalonych, uzyskanie sankcji królewskiej dla ich ważności jawiło się Stanom jako coś oczywistego - albowiem dojście do zgody w drodze konkluzji było w danej sytuacji niemożliwe.

Trudno mi uznać za trafne wywody recenzentów dotyczące sfery ideowoprawnej monografii, związanej z powstaniem Artykułów henrykowskich. Nieprawdą jest, że regulacjami prawnymi, nazywanych przez autorów recenzji błędnie konstytucjami z 1564 i 1569 r., wydanymi na wypadek bezpotomnej śmierci króla, który taką ewentualność przewidywał, państwo zostało zabezpieczone. Gdyby tak było, 1572 r. nie niósłby takiego zamieszania i obaw o los państwa, jakie wraz z zejściem ostatniego Jagiellona nastąpiło. Deklaracje królewskie, mające polityczne podłoże, stwarzały bowiem to, co w sensie ideowym i prawnym stawało się ówcześnie faktem - przecież za życia króla warunkowym - ale już niosącym za sobą określone konsekwencje. Problemu tego recenzenci zdają się w ogóle nie postrzegać. Zupełnie odrębną kwestią było, jak postąpi w takiej sytuacji naród szlachecki, który prawa te w związku z królewskimi zapewnieniami nabył - bądź też, co byłoby innym punktem widzenia, ale także możliwym do przyjęcia - otrzymał je z powrotem w związku z wymarciem swojej dynastii, albowiem źródła władzy niedwuznacznie w rozumieniu ogółu zawsze leżały po stronie narodu, co potwierdzała zarówno doktryna, jak i publicystyka tego okresu.

Rozwiązaniem tych problemów była - jak wiadomo - znana z tradycji, a zastosowana kilkakrotnie w czasach jagiellońskich instytucja elekcji. Przy 
czym forma i sposób jej przeprowadzenia różniły je bardzo, albowiem ówczesne elekcje nie polegały na udziale powszechnym, a jedynie odbywały się przy obecności przedstawicieli narodu. Dla ustawowego utrwalenia instytucji elekcji rozstrzygającego znaczenia nie miały jednak, wbrew poglądowi recenzentów, deklaracje króla Zygmunta Augusta z 1564 i 1569 r., ale ustawy jego ojca, króla Zygmunta I, pochodzące z 1530 i 1538 r., wydane w związ$\mathrm{ku} \mathrm{z}$ elekcją vivente rege Zygmunta Augusta. Miały one charakter regulacji prawno-ustrojowych, utrwalających instytucję elekcji oraz ogólnie określających krąg jej potencjalnych uczestników, jako unusquisque qui vellet - czego, zdaje się, recenzenci nie dostrzegają.

Włączenie do elekcji wszystkich, których uznano za uprawnionych, w której każdy z uczestników, bez względu na przynależność do stanu (senatorskiego czy szlacheckiego) miał jeden równy sobie, wolny głos - co było istotą elekcji viritim, czyniły z niej - nie jak poprzednio, wybór władcy występujący w różnych formach, w których najczęściej rada królewska miała głos rozstrzygający - pierwszą rzeczywistą elekcję w sensie powszechnego i równego udziału. Elekcja monarchy była więc wyrazem suwerennej woli narodu, ale również każdego z jej uczestników, który prawa do tego udziału nabywał z chwilą urodzenia względnie nadania. Recenzenci nie dostrzegają, że rozwój stosunków politycznych w Rzeczypospolitej i świadomości politycznej oraz prawnej przedstawicieli narodu szlacheckiego, potrafiącego przebrnąć najtrudniejszy chyba ze swoich zakrętów dziejowych, a będącego ponadto zdolnym, korzystając ze swoich praw, do dokonania wyboru władzy zwierzchniej, której niezbędność istnienia postrzegano jako coś oczywistego, wyprzedzał epokę. Stąd sprawą jasną było, że skoro tworzono ustawę zasadniczą, jaką Artykuły były, to ustanawiano nowy porządek ustrojowy, w którym zawierano wszystko, co uznano za stosowne, w tym także postanowienia dotyczące wyrzeczenia się dziedziczności, ustanawiania dziedzica w drodze innej niż elekcja narodu.

W tym kontekście za całkowicie naiwne można potraktować pojmowanie przez recenzentów kontraktowego charakteru aktu wyłącznie jako umowy zawartej między osobami prawa cywilnego, do których będą się stosowały normy współczesnego prawa cywilnego. Tymczasem, jak powszechnie wiadomo, każdy akt konstytucyjny o charakterze zasadniczym, jeśli nie jest aktem nadanym, najczęściej z góry, będzie rezultatem - oczywiście w sferze intencjonalnej - zawarcia pewnego konsensusu. Dzieje Artykułów henrykowskich pokazują wyraźnie, że inicjatywa powstania tego aktu leżała po stronie stanowej. Niezależnie też od zmienności formy, w jakiej Artykuły w latach 1573-1576 występowały - można wyraźnie wskazać, że nie tylko u źródeł, ale również w sferze politycznej pojmowano Artykuły jako akt o charakterze kontraktowym. Można oczywiście zastanawiać się, co powodowało stanami, że przyjęły taki sposób rozumienia, mając możliwości narzucenia elektowi 
swojej koncepcji. Powrót zewnętrznie do formuły dualizmu był jednakowoż wygodny w sensie rozumienia aktu mającego stanowić i określać podstawy ustroju.

Przedmiotem szczególnej uwagi recenzentów stała się sprawa Sejmu Rzeczypospolitej. Kwestie dotyczące sejmu, a wynikające z Artykułów henrykowskich recenzenci dotknęli jedynie wycinkowo, chociaż w różnych miejscach swej wypowiedzi. Umknęły natomiast recenzentom sprawy zasadnicze, związane z sejmem, o których w Artykułach było w miarę sporo, a które pokazywały źródła poczynionych w nich regulacji. Stanowiąc bowiem wyraz zmian ustrojowych, obejmujących w swoim instytucjonalnym znaczeniu, obok króla i rady królewskiej, właśnie sejm, dokonywały ustalenia i wyjaśnienia jego pozycji w ustroju Rzeczypospolitej. Moim zdaniem znalazło ono w recenzowanej monografii odpowiednie miejsce. W Artykułach henrykowskich nie konstytuowano przecież Sejmu jako takiego, albowiem był on od lat jedną z najważniejszych instytucji Rzeczypospolitej, której status, jako najwyższego organu władzy państwowej, był ustabilizowany, wręcz trwale co najmniej od konstytucji Nihil novi z 1505 r., formalnie związany z najważniejszym atrybutem suwerennej władzy, jaką jest stanowienie prawa. Istotne natomiast było poddanie ustawowej regulacji w Artykułach henrykowskich bliższego określenia zasad jego funkcjonowania. Zawarcie tych spraw w akcie o charakterze zasadniczym było odejściem od prawa, opierającego działania sejmu na zwyczaju, uzależnionego od funkcjonowania prawnych zasad ustrojowych, wyznaczonego ponadto przede wszystkim praktyką - a przejściem do prawa mającego oparcie w normie konstytucyjnej. Sprecyzowanie zadań oraz generalnych kompetencji sejmu następowało jedynie pośrednio, poprzez inne przepisy określające je zresztą w sposób bardzo ogólny. Umieszczenie tych spraw w osobnej konstytucji o charakterze zasadniczym stwarzało podstawy pod zdecydowane wyjaśnienie pozycji prawno-ustrojowej sejmu, umożliwiającej sprecyzowanie jego wzajemnej relacji w stosunku do innych organów oraz instytucji prawno-ustrojowych Rzeczypospolitej, czyli króla oraz sejmików.

Recenzenci, odnosząc się do szczegółowych kwestii zawartych w monografii, dotknęli przede wszystkim norm organizacyjnych dotyczących sejmu. Nie zauważyli natomiast kwestii istotnych, podając ich uproszczoną, a niekiedy - moim zdaniem - błędną interpretację, zwłaszcza w zakresie monarszego obowiązku zwoływania sejmu co dwa lata, jak i kwestii zamykania obrad sejmowych. Faktem jest, że formułując przepis w ten sposób, projektodawcy Artykułów zakładali, co wynikało z politycznego układu, oczywiste przestrzeganie tych przepisów przez władcę. Sankcja za niewykonywanie obowiązku zwoływania sejmu wynikała z ogólnego przepisu nakazującego przestrzeganie prawa, obejmującego okresowe zwoływanie sejmu, zagrożonego możliwością wypowiedzenia posłuszeństwa. Podany zresztą przez recenzentów jako dowód ich twierdzenia przykład z, ,praktyki życia publicznego Rzeczypospoli- 
tej, w której recenzenci wskazują, że omawiany obowiązek był realizowany, a król dążył nierzadko do częstszego zwoływania parlamentu" - jest o tyle nietrafny, że rozważania dotyczące praktyki politycznej, realizowanej wiele lat po wejściu Artykułów w życie, nie odpowiadają analizie litery prawa, dokonywanej na moment jego wydania. Wyjściową przecież przesłanką zaistniałej różnicy zdań, czy też sposobu rozumienia przepisów, są właśnie sformułowania zawarte $\mathrm{w}$ akcie - o czym akurat była przede wszystkim mowa, a nie ich realizacja, która - jak wiadomo - od normy odbiegała. Mamy zamiast tego przywołane tutaj, a zastosowane w innym kontekście w monografii, określenie terminu zwołania sejmu mianem ,zawitego", co - w rozumieniu recenzentów - dowodzi braku konsekwencji w głoszonych tezach, albowiem nie można tego łączyć z normą o charakterze ius dispositivi. Ale w odniesieniu do normy zawartej w Artykułach henrykowskich oraz praktyki można by wysnuć także inne wnioski. Z jednej bowiem strony termin, chociaż opisowo określony, wyraźnie stanowił, że sejm winien być zwoływany co dwa lata - i praktyka pokazywała, że istotnie tak się działo, a nawet ze względu na potrzeby częściej - ale bywało i tak, że król, mimo obowiązującego go terminu, sejm zwoływał dopiero wówczas, kiedy uznał to za niezbędne. Na marginesie terminologicznych rozważań należałoby jedynie stwierdzić, że gdyby było tak, jak twierdzą recenzenci, że norm ius dispositivum nie można było stosować w praktyce życia publicznego, to nie byłoby i współcześnie sporów konstytucyjnych, ogniskujących się często wokół pytania: czy należy, czy można, czy też jaki jest zakres i charakter danego obowiązku. Podobnie było z problemem ograniczenia długości obrad do 6 tygodni, jako zasady wprowadzonej do ustroju, czy też zamykania obrad, stanowiącą kwestię proceduralną, które należało w Artykułach ustalić, aby zapanował pewien porządek, i które w monografii w odpowiednim miejscu zostały ujęte oraz omówione.

Odmienny od rozważań recenzentów jest mój pogląd na zakres ,spraw sejmowych”. Skąd recenzenci wzięli zdanie, które ujęte jako cytat, miało wskazywać, że wszystkie sprawy pozostałe po sprawach pozostawionych królowi we współdziałaniu z radą zastrzeżono dla sejmu? Stwierdzeniom tym postawiono zarzut przyznania w XVI w. sejmowi domniemania kompetencji. W kwestii tej ponownie daje o sobie znać brak uważnego zapoznania się z literą odnoszącego się do tych problemów przepisu zamieszczonego w Artykułach. Podkreślam, że kompetencje do załatwiania spraw w Rzeczypospolitej zostały rozdzielone na sprawy, które król winien konsultować z radą; były to sprawy obejmujące prowadzenie polityki zewnętrznej i dysponowania wojskiem, dalej sprawy, które zastrzeżono dla sejmu - co określono formułą utique res et negotia comitiis regni publici attinentia propterea nihil preturbantes - jak również sprawy, w których król mógł sam podejmować decyzje. Zakres przedmiotowy spraw sejmowych i królewskich nie był sprecyzowany. Był płynny. Zgodnie jednak z powszechnie obowiązującą zasadą, sprawy, 
które kiedyś postawione zostały w sejmie uważano za sprawy sejmowi przynależne. Pisałem o tym, ale recenzenci tego nie dostrzegli.

Zaskakują wywody recenzentów odnoszące się do poglądów nauki omawianych w monografii. Tu wiele nieścisłości i przekłamań. I tak np. Wacławowi Uruszczakowi nigdy nie przypisywałem poglądu, że koncepcja trójstanowości to osiągnięcie „doktryny konstytucyjnej”, którego powszechne uznanie nastąpiło „od połowy XVI w.” Poglądy W. Uruszczaka, do których się odniosłem, były mi natomiast pomocne w odtworzeniu sytuacji, jaka miała miejsce w latach panowania króla Zygmunta I, do których, rekonstruując grunt dla ukazania ewolucji stosunku władcy z sejmem nawiązywałem, jako do kwestii trafnie przez tego badacza ustalonych. Skąd więc pomysł zarzutu, iż sprawy późniejsze, z czasów króla Zygmunta Augusta, zostały w monografii pominięte? Wystarczy do niej zajrzeć, aby zauważyć ich szeroką ekspozycję, chociażby poprzez również poglądy K. Grzybowskiego. Przywołane zostały one właśnie do tej części dziejów dotyczących relacji władcy z sejmem, której w sposób oczywisty W. Uruszczak nie traktował jako swojego głównego przedmiotu badań, albowiem dotyczyły one panowania króla Zygmunta Augusta, a zaprezentowane zostały w monografii w sposób na tyle czytelny, aby można było je zauważyć i przypisać odpowiedniemu badaczowi. Nie bardzo dokładnie zresztą odnoszą się recenzenci do samych poglądów omawianych badaczy. Przytaczany przez recenzentów Wacław Uruszczak, do którego recenzenci nawiązują, ale czyniąc to niedokładnie, wprawdzie sytuuje króla w określonej relacji do sejmu, w której król (a dotyczyło to czasów króla Zygmunta I), nie będąc częścią składową sejmu, był z kolei jego uczestnikiem oraz obrad sejmowych. Pozycję króla w relacji do sejmu zbliżoną do konstrukcji the King in the Parliament, o czym wspominają recenzenci, zaprezentował natomiast w odniesieniu do czasów króla Zygmunta Augusta, będącego suwerenem, ale działającym w ramach parlamentu, K. Grzybowski ${ }^{1}$, którego recenzenci $\mathrm{w}$ ogóle jako uczestnika tej debaty nie postrzegają. Takie postępowanie recenzentów prowadzi w konsekwencji do nieuprawnionej - moim zdaniem - konkluzji, którą mi przypisano, a której nie wyraziłem (koncepcję trójstanowości sejmu wprowadzono do porządku prawnego ,wskutek zmian, które wniosło przyjęcie Artykułów henrykowskich").

Recenzenci piszą, jakobym „nieświadomie zanegował tezę W. Sobocińskiego, który twierdził, iż Artykuły, stanowiąc powrót do stanowej koncepcji państwa, nie normowały pozycji króla jako „stanu sejmującego, a sytuowały go poza sejmem w pozycji słabszego partnera"2. Niezależnie już od okoliczności, że przytaczają fałszywie poglądy zasłużonego badacza, albowiem

${ }^{1}$ K. Grzybowski, Teoria reprezentacji w Polsce epoki Odrodzenia, Warszawa 1959, s. 34-47, 91-94, 141-146.

${ }^{2}$ W. Sobociński, O ustawie konstytucyjnej państwa polskiego r. 1573, „Czasopismo PrawnoHistoryczne", t. 1, 1948, s. 81-87. 
tezy W. Sobocińskiego nie można wyrywać z kontekstu, to jednocześnie nie można jej przypisywać innego znaczenia, niż je faktycznie posiadała. Łatwo bowiem zauważyć, że kwestie o szczególnej pozycji króla w stosunku do sejmu były politycznym zabiegiem Stanów, które na etapie starania się o uznanie Artykułów przez elekta, obracając problemem formy, był przez Stany postrzegany. Okoliczności (nadzwyczaj delikatne, związane z wyborem władcy, którego brakowało i brak ten, a zwłaszcza przedłużanie się tego stanu, zagrażał egzystencji państwa) nakazywały stanom działanie bez zbędnej zwłoki, ale jednocześnie z pewną ostrożnością. Nie wszędzie i nie zawsze można było podchodzić do elekta z pozycji siły. Stąd fortel z przywilejem, który W. Sobociński - właśnie w tym, a nie w innym miejscu - uznał słusznie za formalne przywrócenie w sferze politycznej - dualizmu władca-stany. W rzeczywistości jednak, w sferze przepisów umiejscawiano go wśród czynników układu ustrojowego, składającego się z trzech stanów: króla, sejmu, rady królewskiej - co zresztą w przepisach Artykułów henrykowskich znalazło widome odzwierciedlenie. Jeśli więc opis pozycji króla oraz stanów, jaki miał miejsce w Artykułach, czyli usunięcie braku regulacji prawnych, było działaniem w celu osłabienia monarchy, a więc stworzeniem podstawy pod konstytucjonalizm stanowej Rzeczypospolitej, jest niewątpliwie kwestią trudną do przyjęcia dla recenzentów, to wypada to jedynie pominąć milczeniem. W tym kontekście zarzut recenzentów, że nie odniosłem się do ustaleń W. Sobocińskiego, jest całkowicie bezzasadny.

Spośród punktów Artykułów henrykowskich, ujętych w zamieszczonej w monografii klasyfikacji i omówionych przez recenzentów, szczególną atencję poświęcili oni punktowi jedenastemu Artykułów, dotyczącemu praw związanych z gruntami szlacheckimi oraz dobrami duchowieństwa. Tymczasem, podnoszone przez nich argumenty uważam za nietrafne. Przede wszystkim podane przez nich prace, w których miało nastąpić dobrze znane omówienie tych spraw - poza wzmiankami, że takie prawo było - nie zawierają niczego więcej. Ponadto, gdyby recenzenci, odnosząc się do tekstu Artykułów przeczytali odpowiednie ich punkty, powinni zauważyć, że kwestie te brzmiały: eos omnes una cum ipsos fructibus, sive etiam mettalis et fodinis (.... $)^{3}$. Podkreślają one, po pierwsze, pojęcie pożytków (fructibus), a po drugie, dodają jednakowoż: ,a oprócz tego metale i kopaliny etc.” (sive etiam mettalis et fodinis etc.), co wyraźnie nie wskazuje na tak jednostronną wymowę tego punk-

${ }^{3}$ Articuli conventus Electionis Generalis Regni, Archiwum Główne Akt Dawnych, Acta terrestria et castriensia Varsaviensia, t. 87, s. 20, dalej: AGAD; Articulos per senatores ac universos Regni Poloniae et Magni Ducatus Lithuaniae Ordines et Status..., E.H. de Noailles, Henri de Valois, t. 3, s. 441; Statuta sub interregno sancita per Serenissimum Dominum Regem Nostrum Electum confirmantur, AGAD Metryka Koronna, 112, k. 14; Confirmatio Serenissimi Electi Regis Poloniae articulorum ad stabiliendum et augendum Reipublicae statum pertinentium, w: Diariusz poselstwa polskiego do Francji po Henryka Walezego. Opr. Adam Przyboś i Roman Żelewski, Wrocław 1963, s. 179. 
tu, jak chcieliby do tego ograniczyć recenzenci, stosując dość powszechnie używane znaczenie tego punktu Artykułów, zawężone tylko do pojęcia regale górniczego.

Warto też podjąć sporny problem posiadania dóbr (a nie wyłącznie własności), albowiem do wykonywania pełni praw wystarczało wykonywanie posiadania nieruchomości ziemskiej w jakiejkolwiek formie prawnej. W czasach, kiedy w stosunkach ziemskich funkcjonowała, obok cechy alodialności, także konstrukcja własności podzielonej, w której kategoria pobierania pożytków odgrywała zasadniczą rolę, akcentowanie eos omnes una cum ipsos fructibus miało swoje znaczenie. Występowało ono jako prawnicza konstrukcja nie tylko w stosunkach z włościanami, ale także między szlachtą i duchowieństwem. Stąd pojęcie ogólnego prawa korzystania z gruntów, zawierające różne ich formy, o których obecnie wspominają recenzenci - ma jak najbardziej prawnicze znaczenie, albowiem pozwala pojmować ten punkt Artykułów, zgodnie z intencją ich projektodawców, bardziej szeroko.

Nie podzielam też uwag recenzentów dotyczących relacji Artykułów henrykowskich do praw kardynalnych z 1768 r. Recenzenci uznają, że polskie prawa kardynalne powinny być przedstawione razem przy okazji omawiania praw w Europie, a nie w miejscu do tego oczywistym, czyli w odniesieniu do spraw z zakresu stosowania prawa ustrojowego w schyłku Rzeczypospolitej. Tym samym nie są konsekwentni. Gdybym umieścił omówienie praw kardynalnych w części poświęconej prawom europejskim, i tylko tam, zapewne spotkałbym się z zarzutem dokonania „rozważań, które należy uznać za zupełnie pozbawione porządku i sensu" - albowiem są to prawa polskie i ich pominięcie przy omawianiu spraw polskich potraktowano by za kardynalny błąd. Gdybym natomiast wspomniał o prawach kardynalnych przy okazji analizy praw europejskim (po czym połączyłbym je ze sprawami polskimi), to z pewnością spotkałbym się z uwagą podobną do tej, jaką uczyniono przy okazji dwukrotnego zajęcia się przeze mnie kwestią paktów konwenta w dwóch różnych miejscach (jak to określili recenzenci - „Autor w dość osobliwy sposób rozbija tę problematykę").

Wychodząc z założenia, że prawa kardynalne, zanim stały się ustawą, były w znacznym stopniu wytworem doktryny ${ }^{4}$, powstającej w ciągu XVII w., w czasie kiedy „dyzmembracja” Rzeczypospolitej poczynała coraz bardziej postępować, zaś w prawie ustrojowym zwyczaj oraz prawne zasady ustrojowe coraz częściej zaczęły zastępować normę stanowioną. W większości też znajdowały się one poza prawem pisanym, jak chociażby mające wpływ na działalność ustawodawczą liberum veto. Między prawem a praktyką życia politycznego pojawił się wyraźny rozziew, przy czym zmiany w ustroju pro-

${ }^{4}$ Z. Radwański, Prawa kardynalne w Polsce. Studia nad historia prawa polskiego, Poznań 1952, s. 9-51. 
wadziły do deformacji ustrojowych, których wyrazem stała się dezintegracja państwa. Zamiast reformy ustrojowej, wyrażonej ustawowo, pojawiła się koncepcja praw kardynalnych, nietykalnych norm wyższego rzędu, obejmujących ogół praw gwarantujących podstawowe wolności szlacheckie, na których ustrój zawisł i których ustrój państwowy miał strzec ${ }^{5}$. Katalog tych zasad, stale rozwijany w ciągu drugiej połowy XVII i pierwszej połowy XVIII w., uzyskał, jak wiadomo, ostateczne swoje ustawowe potwierdzenie w $1768 \mathrm{r}^{6}{ }^{6}$

Jest jeszcze jeden aspekt, który przy wzajemnym określeniu relacji Artykułów henrykowskich w stosunku do praw kardynalnych był niezwykle istotny; stanowi go mianowicie odpowiedź na pytanie: na ile naród tworzący prawo w 1768 r., w przeciwieństwie do narodu z 1573 r., był suwerenny? Czyim instrumentem politycznym, ale też ustrojowym, były Artykuły henrykowskie, które nie uchylone istniały w porządku ustrojowo-prawnym Rzeczypospolitej jako ustawa zasadnicza, chociaż coraz rzadziej się do nich odwoływano $\mathrm{w}$ zmienionych stosunkach polityczno-prawnych - a czyim instrumentem były prawa kardynalne, służące, jak wiadomo, pomimo swojego charakteru ustawy zasadniczej, obcym interesom? A dalej, jaka była zawartość Artykułów henrykowskich, które pomimo swojego niepełnego zakresu, obejmując wiele kwestii, stanowiły realny fundament ustroju Rzeczypospolitej, a jaka była zawartość praw kardynalnych, ograniczonych w swych treściach do kilku zasad ustrojowych, wprawdzie istotnych, ale właściwych dla stosunków polityczno-ustrojowych chylącej się ku upadkowi Rzeczypospolitej? Komu, wreszcie, w ustroju Rzeczypospolitej służyły od strony funkcjonalnej Artykuły henrykowskie, a komu prawa kardynalne? Pierwsze, o czym powszechnie wiadomo, były w większym znaczeniu wyrazem zmian ustrojowych, podczas gdy drugie podsumowaniem istniejących bardziej zwyczajowo zasad prawnych, które mimo swego ustawowego i zasadniczego charakteru, miały petryfikować i tak już wynaturzony ustrój.

IV. Na koniec słów kilka o literaturze przedmiotu oraz sprawach formalnych. Wskazanie na nie jest nieraz cenną wskazówką. Pomijając cierpliwie wypunktowane literówki czy inne tego typu sprawy, w kilku jednak przypadkach należy dać odpowiedź. Błędy formalne zawsze można poczynić, bo w każdej pracy je się znajdzie - co zresztą autorzy recenzji w pewnym momencie łaskawie zauważają, samemu jednak popadając w pułapki. Exemplum stanowi sprawa dzieła Świętosława Orzelskiego, wydanego zarówno w tłumaczeniu polskim Włodzimierza Spasowicza ${ }^{7}$, a następnie w oryginale

${ }^{5}$ Ibidem, s. 3-23.

${ }^{6}$ Volumina legum, wyd. J. Ohryzko, t. 7, s. 595-606, dalej: VL VII.

${ }^{7}$ Ś. Orzelski, Bezkrólewia ksiag ośmioro, czyli dzieje Polski od zgonu Zygmunta Augusta r. 1572 aż do r. 1576 skreślone przez Świętoslawa z Borzejewic Orzelskiego, starostę radziejow- 
łacińskim w opracowaniu Edwarda Kuntzego ${ }^{8}$. Jak wiadomo, między tymi dwoma edycjami istniały różnice, powodujące konieczność podwójnego ich przytaczania. Jeśli więc $\mathrm{w}$ pracy jednokrotnie zostało przytoczone dzieło w polskim tłumaczeniu (przyp. 49 na s. 30) bądź w łacińskiej wersji (przyp. 69 na s. 40 oraz 78 i 79 na s. 43), sytuacja ta oznaczała występowanie przytoczonej informacji tylko w dziele zawartym w przypisie jednokrotnie. Tego rodzaju wyjaśnienie powinno recenzentom starczyć. Podobnie jest z kwestią indeksów, które, jak wiadomo są niezbędne, ale co do których mogą być różne koncepcje ich skonstruowania, przy czym istotne powinno być określenie terminu w tekście. Takiego bowiem hasła, nawet różnie zastosowanego, które znajdzie $\mathrm{w}$ indeksie czytelnik, takiego będzie poszukiwał w tekście, a niekoniecznie wielopoziomowych konstrukcji hasłowych. Na marginesie jedynie tych uwag należy zaznaczyć, że w źródłach słowo ob(o)edientia występuje różnie; pisane jest raz z literą „o”, innym razem w wersji „oe”. W tym konkretnym przypadku, Declaratio króla Stefana z 1576 r. występuje w wersji „obedientia”, co łatwo sprawdzić, chociażby w VL 9 .

Nie do przyjęcia jest ogólnikowa, nie poparta szczegółami i nie znajdująca podstaw generalizująca opinia, jakoby język monografii pełen był występujących częstokroć niezborności składniowych i gramatycznych. Szafowanie takimi stwierdzeniami bez pokrycia, rzuconych na zasadzie luźnego stwierdzenia, mającymi na celu podważenie znajomości języka przez autora, nie mieści się w granicach odpowiedzialności. Sprawę przypisów pominę, albowiem nie jest prawdą, jakoby przytłaczały one tekst. Ich jedynie większe rozbudowanie znajduje się na s. 30-37 i 112-113, 123-135, 138-142, co w porównaniu do całości liczącej kilkaset stron, nie powinno stanowić problemu. Niezależnie od chybionych merytorycznie zarzutów recenzentów, dotyczących konstrukcji przypisów, wypada pamiętać, że ich tworzenie, sposób i rozdział treści między nimi a tekstem głównym należy do dyskrecjonalnych uprawnień autora.

Co do uwag dawanych w zakresie literatury przedmiotu. Wszystkie prace zostały przeze mnie wymienione i przytaczane w tekście monografii w takim zakresie, w jakim było to przydatne. Stąd recenzenci nietrafnie wyprowadzają wniosek, stanowiący zarzut, że w pracy nie wykorzystano odpowiednio źródeł, do których należy chociażby znana edycja pism z okresu Pierwszego Bezkrólewia, jakiej dokonał ponad sto lat temu Jerzy Czubek ${ }^{10}$. Twórca tej publikacji, działając na zlecenie Akademii Umiejętności, zebrał w ramach kilkuletnich badań prawie wszystkie druki czy rękopisy polityczne z okresu bezkrólewia po śmierci króla Zygmunta Augusta, znajdujące się w archiwach.

skiego. Przełożyt z rękopisu Cesarskiej Publicznej Biblioteki, przypisami i życiorysem uzupetnit Włodzimierz Spasowicz, Petersburg 1856.

${ }^{8}$ Ś. Orzelski, Interregni Poloniae libri VIII, wyd. Edward Kuntze, Kraków 1917.

${ }^{9}$ VL II, s. 923.

${ }^{10}$ Pisma polityczne z czasów pierwszego bezkrólewia, wyd. J. Czubek, t. 1-3, Kraków 1906. 
W większości były to prace z zakresu czystej publicystyki. Ile było tam ,projektów poprawy praw z konkretnymi propozycjami rozwiązań" - o których wspominają recenzenci - sami byliby wiedzieli, gdyby zapoznali się z wydawnictwem J. Czubka. Wówczas nie byłoby miejsca na zbędne rozważania „o poprawie praw”. Gdyby jeszcze uważniej przeczytali tekst recenzowanej monografii, to niechybnie byliby spostrzegli, że publicystyka była czymś innym niż proces chociażby koncypowania konkretnych postanowień, które znalazły później odzwierciedlenie w końcowym akcie z 12 maja 1573 r. Pytanie, kto je tworzył, czym się kierowano przy ich powstawaniu - pozostanie do końca nieodgadnioną tajemnicą, albowiem z wydarzeń tych nie zachowały się bezpośrednie materiały, a jedynie pośrednie informacje, podawane $\mathrm{w}$ mniej lub bardziej wiarygodny sposób.

V. Uznać można, że krytyka naukowa ma prawo być napastliwa, ale tylko wówczas, kiedy jest pożyteczna. Tymczasem w odniesieniu do omawianej monografii trudno nie ukryć wrażenia, że artykuł napisany został ze z góry zamierzonym założeniem, iż ocena monografii ma wypaść na „nie” - a to, co na wstępie zostało negatywnie sformułowane jako teza, miało być uwieńczone określoną konkluzją w końcu wystąpienia - co zresztą zostało uczynione.

W wystąpieniu autorów recenzji nie ma przede wszystkim omówienia, czy przynajmniej zauważenia problemu, czyli skupienia się wokół kwestii, czym Artykuły henrykowskie były - i jak zostało to przedstawione. Gorzej jeszcze, że praktycznie nie wiadomo, jaki jest tak naprawdę stosunek autorów recenzji do samych Artykułów henrykowskich i ich roli w dziejach ustrojowych Rzeczypospolitej. Podejmując się bowiem zrecenzowania monografii dotyczącej Artykułów, mając sposób postrzegania zaburzony określoną tezą, recenzenci zabrnęli w ewidentne sprzeczności: raz bowiem, zwłaszcza na wstępie, podnosili ich fundamentalne znaczenie, w innych przypadkach, znacznie częstszych, kwestionowali de facto ich rolę, skoro podkreślali „hiperbolizowanie” znaczenia Artykułów, którego doszukiwali się w monografii, tak jakby nie zdawali sobie sprawy z tego, że mamy do czynienia z ustawą zasadniczą. Wyrażając $w$ ten sposób swoje przekonanie, recenzenci dążyli do wytworzenia jednostronnie negatywnego obrazu całości.

Sposoby takiego postępowania widać chociażby po pobieżnie sporządzonym zestawieniu prac, które miałyby być poświęcone Artykułom henrykowskim, co ujawnia jeszcze jedną kwestię. Zdaniem bowiem autorów recenzji - wbrew rzekomo moim twierdzeniom - doczekały się Artykuły henrykowskie „,szeregu publikacji, nie zawsze przecież wyłącznie krytycznych, w tym także analiz historyczno-prawnych”. Wskazali przy tym recenzenci na prace Stanisława Płazy ${ }^{11}$,

${ }^{11}$ S. Płaza, Próby reform ustrojowych w czasie pierwszego bezkrólewia [1572-1574], Kraków 1969. 
W. Sobocińskiego ${ }^{12}$, Tadeusza Pilińskiego ${ }^{13}$, Stefana Gruszeckiego ${ }^{14}$, Ewy Dubas-Urwanowicz ${ }^{15}$. Lista tych pozycji potwierdza, że autorzy tych twierdzeń prawdopodobnie prac tych nie czytali. Wyjątek stanowi praca W. Sobocińskiego, chociaż jest ona artykułem, a nie monografią, zawierającym jednak liczne cenne uwagi, w której autor zachęcał do napisania monografii o Artykułach henrykowskich. Pozostałe prace, wprawdzie ocierając się o problematykę Artykułów, bo trudno ją było pominąć, dotyczą jednak spraw zupełnie innych, przede wszystkim problemów związanych z bezkrólewiem. W żadnym przypadku nie były one analizami historycznoprawnymi.

Najbliżej teoretycznie był tego problemu S. Płaza. Praca jednakże jego stanowiła $\mathrm{w}$ większości dość wierne streszczenie wątków wydarzeń pochodzących z dzieła Ś. Orzelskiego, wręcz z zachowaniem jej układu, jak chociażby w prezentacji ugrupowań z okresu bezkrólewia, zaś w zakresie innych źródeł oparta była generalnie na ukrytych w pogmatwanych przypisach materiałach trzech tomów pochodzących z zasobów Biblioteki Muzeum Narodowego im. Czartoryskich, vol. 80, 81 i 82. Dopiero w części końcowej S. Płaza zajął się bliżej Artykułami, ale były to ciągle bardziej rozważania polityczne, omawiające przebieg wydarzeń z szeroko pojmowanego okresu bezkrólewia, sięgające zresztą i tak co najwyżej sejmu koronacyjnego króla Henryka, a nie dalej, oparte $\mathrm{w}$ większości na literaturze. W żadnym natomiast wypadku nie była to analiza historycznoprawna Artykułów, mimo że autor, nie zamieściwszy spisu źródeł, literatury przedmiotu, indeksów, poprzestając tylko na spisie skrótów, dołączył do swojej pracy tekst Artykułów, ale będący przedrukiem wydawnictwa Adama Przybosia i Romana Żelewskiego, Diariusz poselstwa polskiego do Francji po Henryka Walezego w 1573 r. (1963), opartym na Metryce Koronnej, w której zamieszczono tekst polskiego thumaczenia konfirmacji Artykułów, dokonanej przez króla Henryka w katedrze Notre Dame 19 września 1573 r. ${ }^{16}$ W tym kontekście nie do przyjęcia jest konkluzja negatywnej tezy o monografii, postawionej przez recenzentów na początku ich wypowiedzi, że jest ona „rozczarowaniem i utraconą szansą na otwarcie na nowo badań nad Artykułami henrykowskimi, zaś każdy historyk, czy historyk prawa pragnący zdobyć wiedzę, czy prowadzić badania nad Artykułami henrykowskimi za punkt wyjścia do swych rozważań nadal będzie musiał przyjąć klasyczne opracowania głównie pióra S. Płazy i W. Sobocińskiego". Stawianie tego rodzaju tez bez pokrycia, niewystarczająco udokumentowanych, jest - moim zdaniem - nieuprawnione.

${ }^{12}$ W. Sobociński, O ustawie konstytucyjnej państwa polskiego z r. 1573, CPH, t. 1, 1948, s. 75-89.

${ }^{13}$ T. Piliński, Bezkrólewie po Zygmuncie Auguście i elekcya króla Henryka przez Tadeusza Pilińskiego, Kraków 1872.

${ }^{14}$ S. Gruszecki, Walka o władzę w Rzeczypospolitej po wygaśnięciu dynastii Jagiellonów 1572-1573, Warszawa 1969.

${ }^{15}$ E. Dubas-Urwanowicz, Koronne zjazdy szlacheckie w dwóch pierwszych bezkrólewiach po śmierci Zygmunta Augusta, Białystok 1998.

${ }^{16}$ Diariusz poselstwa polskiego, s. 175-183. 